
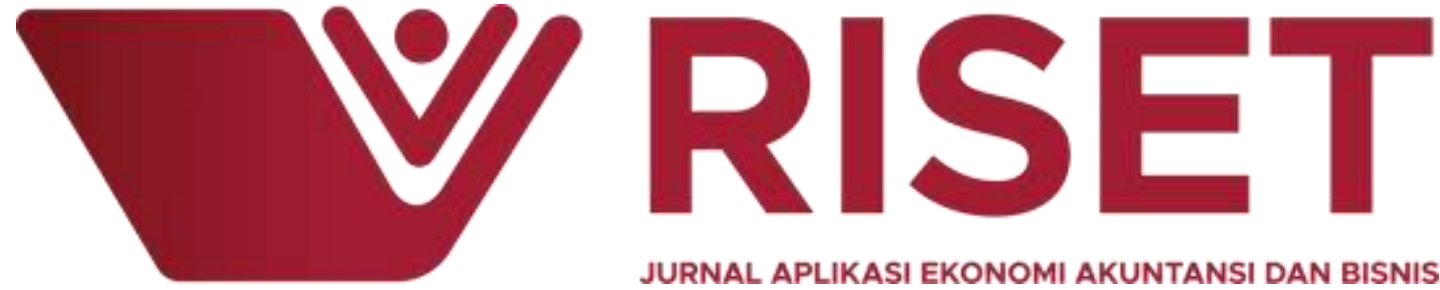

JURNAL APLIKASI EKONOMI AKUNTANSI DAN BISNIS

\title{
EVEN NUMBER BOARDS IN INDONESIAN COMPANIES
}

\author{
Martha David ${ }^{1)}$, Rita Juliana ${ }^{2)}$ \\ 1,2) Program Divisi Manajemen Fakultas Ekonomi dan Bisnis Universitas Pelita \\ Harapan
}

\section{INFO ARTIKEL}

Even Number Boards in Indonesian Companies

Submitted:

28 - Februari - 2020

Revised:

12 - Maret - 2020

Accepted:

30 - Maret - 2020

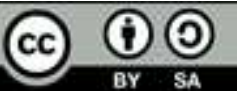

\begin{abstract}
The recent globalization has forced firms throughout the world to enhance the performance. The aim of this research is to prove that corporate boards with even number of directors have inadequate corporate governance activities, to prove that corporate boards with even number of directors have inadequate agency problems and to prove that corporate boards with even number of directors decreases firm value, measured by meetings, expenses and market value of equity. The data is collected from the annual financial reports of 197 companies in 2013-2017 period, with a total of 985 company-year observations. The analysis is conducted using panel data regression method after going through diagnostic test. The results of this analysis show that even number of directors does impact corporate governance activities, causes inadequate agency problems and affects firm value. Firms with even number of boards is found having less meeting, greater expenses and lower market value of equity.
\end{abstract}

Keywords: Corporate governance; Panel data regression; even number boards; firm value

E-mail: rita.juliana@uph.edu²

\section{INTRODUCTION}

The new stage of competition does need a lot of enhancement and improvement for every company that wants to strive for the best. The enhancement and improvement are not only limited to the business monetizing process like core product value and marketing. Further than that, beyond what is visible on the surface, a company does also need enhancement and improvement in their corporate governance. Great enhancement and improvement need great corporate governance, which comes from the commitment of the top management. That also includes the firm alignment between shareholders and 
all the board of directors in the company. This is to reassure that the company will have measurable act and risk management for the future plan and decisions.

Magdi and Nadereh (2002) explain that corporate governance is about ensuring the business is running well until investors able to get their share returns. Drobetz et al. (2003) explained that corporate governance is efforts to optimize a company's management system and it's monitoring to solve agency problem of information asymmetries. Corporate govenance also provides the structure through which the companies' objectives are set and the means of attaining these objectives and monitoring performance (Wolfensohn, 1999 and Uche, 2004).

By seeing how important Corporate Governance is, this research rise the importance of corporate governance, particularly the role of the board of directors. Among that factors, there is one rising factor that discuss about board of directors who holds important key in corporate governance, which is even and odd number board of directors. This one factor will become our main discussion.

Every company have their own board of directors. The member of director boards is elected normally by the shareholder of the company. They are elected to govern the company and look after the shareholder' interests. Every board of directors has power in decision making. They are empowered to set the company's rules, recommend and appoint members for the company, hire-monitor-evaluate every members of the company, determine about shares or dividends. In other sides, they are expected to play a critical role in monitoring management and safeguarding minority shareholders' rights (Mace, 1986). Among board of directors, there should be few numbers of independent directors that helped more to monitor executives. Independent directors are board of directors that has no relation with any executives, haven't worked so long for the company or even come from outside the company. This is conducted in Indonesia Stock Exchange Regulation Number I-A on the Listing of Shares and Equity Securities other than Shares issued by Listed Company (KEP-00001/BEI/01-2014). This regulation is made in attempt improve the quality of Listed Companies and Liquidity of Public Company Shares by reminding director to not lose their independence also objectivity, according to Indonesia Stock Exchange.

While previous papers show the importance of the board of directors in the corporate governance conduct, it still not obvious the impact of the even and odd number of the board. In every company meeting, boards have the power in decision making. Because there are several numbers of boards, there should be votes in decision making process. If there's odd number of members, the vote won't be tie. But viceversa, with even number of board members, the vote will be tie and the decision of more-powerful member will be chosen at the end. This prove even number of boards are not effective in decision making, including problem solving and monitoring managers. This supported by Deng et al. (2012) that company with even boards have lower Tobin's Q and operating performance. Agency cost can lead to poor accounting quality because corporate insiders are likely to manage accounting numbers to camouflage their consumption of private benefit of control (Leuz et al., 2003). A company with poor corporate governance and inadequate agency problems have lower valuation in equity market with Tobin's Q.

In addition, Gao and Huang (2016) show even numbers of directors are associated with lower quality of committee decisions. They also found a supporting fact that even number of directors in audit committee is associated with lower likelihood of financial restatement. These findings are also backed up with a recommendation from American Institute of CPA on why audit committees should be composed of an odd number of directors to better handle the matters requiring a vote. 
Another important role of boards is to recommend and appoint members of the company including executives or the board itself. The problem in emerging markets where firms have dominated ownership and powerful shareholder might hand-pick its own members and executives for several people's interest so the purpose of board directors itself can't be done. If there's odd numbers of members, there should have discussion regarding the topic and the board of directors or executive won't be dominated by certain parties only (He and Luo, 2018).

The case stated above about agency cost and especially about the problems caused by even numbers of directors can be concluded as a risk and a threat for companies. The problem caused by the even numbers of directors will not only damage the firm performance but potentially image and value of the company as well in the eye of public. Our study contributes on the corporate finance study by filling the gap in the corporate governance area. This study aims to show whether even number can caused less corporate governance activities and increase the agency cost. This question also relates with the impact of corporate governance on the value of the firm.

In this study, we find that Indonesian firms with even numbers tend to conduct less meeting, which also mean less corporate governance quality. Interestingly, our study result also show that firms with even number board members have higher agency costs. This result similar with He and Luo (2018) findings that even board members caused higher agency problems that leads to higher agency costs. We also show that even number board decrease firms' market value.

\section{LITERATURE REVIEW}

\section{Corporate Governance}

Corporate governance is basically a distribution of rights and responsibilities to those who are involved, ruled by regulations and procedures in making decisions. Thus, corporate governance provides the structure through which the companies' objectives are set and the means of attaining these objectives and monitoring performance (Wolfensohn, 1999 and Uche, 2004).

Bad corporate governance will risk firm performance up to a measure that a company could go down dramatically such as the case of Enron and Parmalat which has collapsed in the past decade (Dibra, 2016). He and Luo (2018) mentioned that firm performance is related to some features such as percentage of independent directors, board hierarchy, female directors, and foreign directors. He and Luo (2018) also found in their research that even number of directors sitting on the board is related to firm performance.

Liang et al. (2013) who find that independent directors affect firm performance uses 50 banks in China as their research sample. While they use regression as the method of analysis, they find that the regression result of independent directors as a control variable shows a positive and significant result. Given the result, they conclude that independent directors indeed affect firm performance in a positive way, meaning that the more independent directors a company have, the better firm performance that will be achieved.

Zhu et al. (2016) find that board hierarchy affect firm performance. The research uses 4,350 company-year as the research sample. Zhu et al. (2016) research result shows that independent directors who are ranked higher are more likely to vote against the management, especially on financial reporting issues like earnings management. The 
higher independent-director rankings are also found associated with less earnings management.

\section{Agency Problem and Agency Cost}

Agency problem is appear in the firms because of the separation of owners and managers. Jensen and Meckling (1976) later explains that agency theory has two different economy subjects: principal and agent. Agency theory basically speaks about a contract where a principal of one or few people command other people (agent) to do some sort of services under the name of its principal while also giving the authority to the agent to decide the best for the principal. Agency theory generally describe the relationship of shareholders as the principal and management as the agent. The company management is the party bond to the contract issued by the shareholders to work in their favor. Company management is accountable to the shareholders regarding all policy and action item created by the management.

Jensen and Meckling (1976) mentioned that the issues come from the existence of agent and principal is that agent doesn't always make decisions that always favor principal's interest. One of the main assumptions of Agency Theory is that the different goal between principals and agents can spark conflicts because the board of directors (agents) are focusing on achieving their own goal which is to focus on projects and company investment to gain great profit in the short term instead of focusing on long term planning as per shareholders (principal) goal. The effort on reducing these problems, however, inflicts an extra cost called agency cost that will be sorted out by both agents and principals.

Jensen and Meckling (1976) classifies the agency cost into three different costs: monitoring cost, bonding cost and residual loss. Monitoring cost is a cost accounted to the principals to monitor agent's behavior, which is to measure, supervise and control all agents working with them. Bonding cost is a cost accounted to agent's side to create and obey a mechanism that will make sure that agents will act for the interest of the principals. The final cost, residual loss, is a loss of principal's welfare as the outcome of the difference between agent's decisions and principal's decision.

The board of directors are expected to do their core responsibilities efficiently. However, if the board of directors fail to do their function, it will create high agency problem and incurring high agency cost such as to hire independent director or auditor (Jiang and Kim, 2015). Gao and Huang (2016) found a supporting fact that odd number of directors in audit committee is associated with lower likelihood of financial restatement, less off-balance sheet activities involved in a firm and lower possibility of restating financial reports, compared to firms with an even audit committee do.

\section{Hypothesis}

As corporate governance is a very important factor of company's success. A bad corporate governance could lead a company straight into its' darkest time just like the case of Enron and Parmalat that happened on the last decade (Dibra, 2016). He finds that board of directors who holds important key in corporate governance, which is even and odd number board of directors.

Every company have their own board of directors. The member of director boards is elected normally by the shareholder of the company. They are elected to govern the company and look after the shareholder' interests. In every company meeting, boards have the power in decision making. Because there are several numbers of boards, there 
should be votes in some kind issues or new ideas coming out. If there's odd number of members, the vote won't be tie and there will be some-kind of decision for every problems or idea arise. But vice-versa, if we have even number of members, the vote will be tie and the decision of more-powerful member will be chosen at the end, and to further extent this can cause the meeting purpose to be biased which also lead to less meeting held in a year (He and Luo, 2018). This prove even number of boards are not effective in decision making, including problem solving and monitoring managers.

Based on the findings and facts that show company with even number of directors have more complicated process in company meetings, decision making and some other aspects of a corporate governance, the first hypothesis of this research is that firm with even number of directors have inadequate corporate governance.

\section{HI: Firm with even number of directors have inadequate corporate governance activities}

As He and Luo (2018) explains about how even numbers of directors can affect the firm performance in China added some additional agency problems compared to the company with odd board observed from some findings in company with even boards such as higher tunneling through intercorporate loans, higher expenses ratios, less number of board meetings and higher likelihood of absence of directors in board meetings, this research also come up with the same theory that then produce a hypothesis of company with even number of directors will have more agency problems.

The agency problem indicator that will be the focus of this research is the expense ratio, calculated as the sum of administrative and sales expenses scaled by revenues or the administrative expenses scaled by revenues. A common form of agency cost is the insiders' excessive consumption of perquisites or perks. The perk consumption results in higher administrative and/or sales expenses.

Based on the findings that show company with even number of directors have more agency problems more than firm with odd numbers, the second hypothesis of this research is that firm with even number of directors have inadequate agency problems more than firm with odd number of directors.

\section{$\mathrm{H}_{2}$ : Firm with even number of directors have inadequate agency problems more than firm with odd number of directors.}

Gao and Huang (2016) find the correlation between even-odd nature of audit committees and earnings quality of a company. This is added by Deng et al. (2012) that finds company with even boards have lower Tobin's $Q$ and operating performance. Agency cost can lead to poor accounting quality because corporate insiders are likely to manage accounting numbers to camouflage their consumption of private benefit of control, according to Leuz et al. (2003). A company with poor corporate governance and inadequate agency problems have lower valuation in equity market with Tobin's Q. Beside the earnings quality, He and Luo (2018) also finds that firms with even boards in China have strong correlation with lower market value of equity and smaller Tobin's Q. The result from He and Luo (2018) shows that agency problems related to even boards may result in investor's discounting the share prices and at the end will lower firm valuation.

Based on the findings that show company with even number of directors have lower earning quality, proved by the higher likelihood of financial restatement, the third 
hypothesis of this research is that even numbers of directors affect the firm value of a company.

\section{H3: Even number of directors affects firm value negatively. RESEARCH METHODOLOGY}

\section{Data}

This research is using samples from company listed in Indonesia Stock Exchange (IDX) which published annual report from 2013 until 2017. This study use proposive sampling, we select our sample based on our sample criteria shown in Table 1. From 570 companies that has been recorded, there are some got eliminated because they don't have complete annual report needed, or they haven't been listed in the period needed. Some company listed in this several industries will also be eliminated: Finance, Trade, Service and Investment because they have huge different in capital structure compare to other industry and have lot of restrictions.

Table 1. List of Sample

\begin{tabular}{|l|c|}
\hline Total companies listed in IDX & 570 \\
\hline $\begin{array}{l}\text { Total companies that is not listed, unpublic } \\
\text { along the period above or just listed along the } \\
\text { period above }\end{array}$ & 187 \\
\hline $\begin{array}{l}\text { Total companies didn't have complete annual } \\
\text { report or didn't publish any }\end{array}$ & 98 \\
\hline $\begin{array}{l}\text { Total companies in Finance, Trade, Service, } \\
\text { Investment Industry }\end{array}$ & 92 \\
\hline $\begin{array}{l}\text { Total companies that will be used as sample } \\
\text { in this research }\end{array}$ & 197 \\
\hline
\end{tabular}

\section{Empirical Model}

Based on the previous research conducted by He and Luo (2018), the model to measure agency problems in a company with even board is:

$$
\begin{aligned}
& \text { DEP }=a+\beta_{1} \text { Even }_{i t}+\beta_{2} \text { Board_own }_{i t}+\beta_{3} \text { Board_size }_{i t}+\beta_{4} \text { FCF }_{i t} \\
&+\beta_{5} \text { Independence }_{i t}+\beta_{6} \text { Leverage }_{i t}+\beta_{7} \text { MT }_{i t}+\beta_{8} \text { ROA }_{i t} \\
&+\beta_{9} \text { Size }_{i t}+\beta_{10} \text { ST }_{i t}+\beta_{11} \text { Stock_Volatility }_{i t}+\beta_{12} \text { Tangible }_{i t} \\
&+\beta_{13} \text { Top }_{i t}+\beta_{14} \text { Top2_ } 5_{i t}+\varepsilon_{i t}
\end{aligned}
$$

$D E P$ is the measure of our dependent variables. Our variable of interest is Even $_{i t}$, which is a dummy variable equal to 1 for firms that have an even number of directors on their board, and 0 for firms with an odd number of directors. We expect $\beta_{1}$ to be positive on agency cost regression and negative on meeting numbers and market value, 
suggesting that firms with an even number board members have more agency problems and lower corporate governance quality.

In this research, the dependent variables are (1) Market Value (MV), we measure agency costs by calculating (2) the expense ratio calculated as the sum of administrative and sales expenses scaled by revenues (EXPENSE1) and (3) the administrative expenses scaled by revenues (EXPENSE2) and (4) numbers of board meeting per year (MEETING).

Meeting

: Natural Logarithm of number of meeting

EXPENSES1

$: \frac{\text { Adm.Expense }}{\text { Sales Expense }}$

EXPENSES2

$: \frac{\text { Adm.Expense }}{\text { Revenue }}$

MV

: Natural Logarithm of Firm's market value

Board_own $n_{i t}$ is the sum of the share percentage of all board directors. Board_size $_{\text {it }}$ is the number of board members in a company. $F C F_{i t}$ is the ratio of net operating cash flow divided by total assets in the year $\mathrm{t}-1$. Independence ${ }_{i t}$ is the ratio of the number of independent directors divided by the number of total board members. Leverage $_{i t}$ is the ratio of total liabilities divided by total assets at the end of year $\mathrm{t}-1$. $M T B_{i t}$ is the ratio of stock price to book value per share at the end of year t-1. $R O A_{i t}$ is the ratio of net income divided by total assets by the end of year $\mathrm{t}-1$. Size ${ }_{i t}$ is the natural logarithm of the total assets at the end of year $\mathrm{t}-1 . S T_{i t}$ is a dummy variable for company that reported accounting losses consecutively in the past two years. Stock_Volatility ${ }_{i t}$ is the standard deviation of a focal firm's daily stock returns in the year t-1. Tangible $_{i t}$ is the ratio of tangible assets divided by total assets at the end of year $\mathrm{t}-1$. Top $1_{i t}$ is the share percentage of the largest shareholder at the end of year $\mathrm{t}-1$. Top $25_{i t}$ is the sum of the share percentage of the second to fifth largest shareholders at the end of year $\mathrm{t}-1$.

\section{RESULTS AND DISCUSSION}

\section{Descriptive Statistics}

Table 2 shows the descriptive statistic from 197 sample companies in Indonesia within 5 years period, resulting a total of 985 observations. The result on table 2 have gone through winsorization process at the level of one percentile. Even has an average of 0.4558376 which means that $45.6 \%$ of Indonesian companies have even number of directors.

Table 2. Descriptive Statistics

\begin{tabular}{lllrr}
\hline \multicolumn{1}{c}{ Variables } & Mean & \multicolumn{1}{c}{ S.D } & \multicolumn{1}{c}{ Min } & \multicolumn{1}{c}{ Max } \\
\hline Even & 0.4558376 & 0.4982989 & 0 & 1 \\
MEETING & 3.1646950 & 0.3848732 & 1.3862940 & 3.9512440 \\
Expense_l & 0.9578376 & 0.3522056 & 0.4554870 & 3.4999320 \\
& & 248 & &
\end{tabular}




\begin{tabular}{lrrrr} 
Expense_2 & 0.2414253 & 0.3457218 & 0.0149606 & 2.7383150 \\
MV & 28.1946600 & 2.0601000 & 24.3968400 & 33.3377800 \\
Board_Ownership & 0.4346110 & 0.1606671 & 0 & 2.3692710 \\
Board_Size & 5.0548220 & 1.9503590 & 1 & 12 \\
FCF & 0.0662525 & 0.1046712 & -0.2027172 & 0.4410893 \\
Independence & 0.1396957 & 0.1212656 & 0 & 0.6666667 \\
LEVERAGE & 0.5721554 & 0.3682742 & 0.5366920 & 2.6362880 \\
MTB & 2.2354170 & 3.8793710 & -1.1726540 & 28.6337200 \\
ROA & 0.5275300 & 0.1089149 & -0.2468278 & 0.5644975 \\
SIZE & 28.6537400 & 1.6451680 & 25.1616900 & 32.3438700 \\
ST & 0.2101523 & 0.4076236 & 0 & 1 \\
Stock_Volatility & 0.0505808 & 0.0325016 & 0 & 0.1938326 \\
Tangible & 0.3489658 & 0.2525054 & 0.0020240 & 1.2155240 \\
Top1 & 0.6935239 & 2.7692620 & 0.0302799 & 81.8547600 \\
Top2_5 & 0.4954128 & 1.5867070 & 0.0066999 & 46.5329800 \\
\hline Source: data analySis & & & & 0
\end{tabular}

Source: data analysis

\section{Regresion Results}

This section will describe the regression of all research model. After going through all the steps of the research and given the fact that most models have diagnostic problem, this research uses Discroll-Kraay Standard Error to overcome the autocorrelation, heteroskedasticity and cross-sectional dependence problems.

Table 3. Panel Regression Results

\begin{tabular}{lllll}
\hline & Number of meeting & EXPENSE1 & EXPENSE2 & Market Value \\
\cline { 2 - 4 } Even & \multicolumn{2}{c}{ Observed Coefficient } \\
board_ownership & -0.281402 & $0.274333 * * *$ & $0.355352 * * *$ & $-0.0611402 * * *$ \\
board_size & $-0.071993 * * *$ & -0.158064 & 0.0055365 & $0.1976263 * * *$ \\
FCF & 0.0014595 & 0.0023101 & $0.0566622 * * *$ \\
independence & -0.1160462 & $-0.2787861 * * *$ & $-0.1664657 * * *$ & -0.0683367 \\
LEVERAGE & $-1.009028 * * *$ & $0.1353492 * * *$ & $0.3324236 * * *$ & $0.5924919 * * *$ \\
MTB & 0.0105081 & -0.465468 & $-0.1216779 * * *$ & $-0.2294098 * * *$ \\
ROA & $-0.0122882 * * *$ & $0.172226 * *$ & $0.0113335 * *$ & $0.538368 * * *$ \\
Size & -0.0789051 & $-0.869862 * * *$ & $-0.633425 * * *$ & $1.552301 * * *$ \\
st & $-0.071993 * * *$ & 0.518132 & -0.0230544 & $0.3784308 * * *$ \\
VOL & $-0.0341477 * * *$ & $0.1137548 * * *$ & $0.0845892 * * *$ & $-0.0860281 * * *$ \\
TANGIBLE & $3.283693 * * *$ & 0.4561099 & 0.1662406 & 1.001891 \\
top1 & $-0.165798 * * *$ & $-0.0743177 * * *$ & -0.0336413 & $0.2443485 * * *$ \\
top2_5 & $0.0023124 * * *$ & $0.0069424 * * *$ & $0.0088055 * * *$ & $0.0041687 * * *$ \\
cons & $-0.0154418 * * *$ & $-0.0294979 * * *$ & $-0.0405534 * * *$ & 0.0009492 \\
F-stat & $13.22858 * * *$ & -0.5237978 & 0.915372 & $16.81294 * * *$ \\
$\boldsymbol{R}$-squared & $\mathbf{2 0 9 . 9 1}$ & $\mathbf{1 1 4 . 5 3}$ & $\mathbf{4 3 . 1}$ & $\mathbf{2 1 7 . 4 2}$ \\
\hline & $\mathbf{0 . 2 0 8 3}$ & $\mathbf{0 . 2 9 6 8}$ & $\mathbf{0 . 2 3 3 7}$ & $\mathbf{0 . 1 7 5 1}$ \\
\hline
\end{tabular}


* Significant at $10 \%$ level, ** Significant at 5\% level, *** Significant at $1 \%$ level Source: data analysis

Table 3 shows that Even independent variable is significant towards "number of meeting" dependent variable This shows that even number of boards does have effects on corporate governance activities. Similar with He and Luo (2018), even number board members decrease the corporate governance quality. In every company meeting, boards have the power in decision making. Because there are several numbers of boards, there should be votes in some kind issues or new ideas coming out. The initial idea of how even number of directors could affect corporate governance activity is that if there's even number of members in the meeting, the vote can be tied and the decision of morepowerful member will be chosen at the end and to further extent this can cause the meeting purpose to be biased which also lead to less meeting held in a year. Less meeting means weaker monitors, and this goes along with the hypothesis that even boards will have unfavorable corporate governance.

The effect of even number of boards on agency problems is significant. This is proven by the findings in table 3 that Even is found significant on both EXPENSE1 and EXPENSE2, with a positive effect to both variables. This means that a firm with even boards will have higher ratio of the sum of administrative expenses and sales expense divided by revenues along with the higher ratio of the sum of administration expense and general expense divided by revenue. The findings are reinforced by the previous findings by He and Luo (2018) that also researched about the effect of even number of directors toward agency problems. He and Luo (2018) finds that even number of directors has a significant positive effect with the increase of EXPENSE1 and EXPENSE2 ratio. This goes along with the hypothesis that firms with even boards will have more agency problems, and in this case, higher expenses ratios.

The effect of even number of boards on firm value is perfectly explained by the findings that Even is found significant with a negative effect on "Market Value". This means that even number of boards will decrease firm value known by its' market value of equity, at least lower than the firms with odd number of boards that are included in this research. This finding is reinforced by He and Luo (2018) that also conducted a research on how even number of directors affect firm value. He and Luo (2018) finds that even number of directors have negative effect on market value of equity (Market Value). This goes along with the argument that if even number of boards are associated with more agency problems, then it is also predicted that the firm with even number of boards will have lower valuation of the equity.

\section{CONCLUSION}

This study is conducted to fill the research gap on the corporate governance study. Although there is wide coverage in corporate governance area, the study on the impact of the even number board of directors is still limited. Our result show that even number of boards affects corporate governance negatively. Firms with even number of boards have less meeting and less control. In other words, corporate governance in even number boards firms are perform poorly compared to firm with odd number of boards. Moreover, even number of boards positively affects agency costs in a firm. We show 
that firms with even number of boards have higher expense ratio compared to firms with odd number of boards. Additionally, even number of boards affects firm value negatively. The findings show that firms with even number of boards have lower firm value compared to firms with odd number of boards. This results show that the number of boards is an important element in evaluating firm's corporate governance conduct.

\section{REFERENCES}

Deng, X., Gao, H., \& Liu, W.-L. (2012). Voting Efficiency and the Even-Odd Effects of Corporate Board: Theory and Evidence. Journal of Economic Literature.

Dibra, R. (2016). Corporate Governance Failure: The Case of Enron and Parmalat. European Scientific Journal, 50-62.

Drobetz, W., Schillhofer, A., \& Zimmermann, H. (2004). Corporate governance and expected stock returns: Evidence from Germany. European financial management, 10(2), 267-293.

Gao, H., \& Huang, J. (2016). The Even-Odd Nature of Audit Committees and Corporate Earnings Quality. Journal of Economic Literature.

He, W., \& Luo, J.-h. (2018). Agency problems in firms with an even number of directors: Evidence from China. Journal of Banking and Finance, 139-150.

Jensen, M. C., \& Meckling, W. H. (1976). Theory of the Firm: Managerial Behavior, Agency Costs and Ownership Structure. Journal of Financial Economics, 3(4), 305-360.

Jiang, F., Kim, K., 2015. Corporate governance in China: A modern perspective. Journal of Corporate Finance 32, 190-216.

Leuz, C., Nanda, D., \& Wysocki, P. (2003). Earnings management and investor protection: an international comparison. Journal of Finance and Economics, 505-527.

Liang, Q., Xu, P., \& Jiraporn, P. (2013). Board characteristics and Chinese bank performance. Journal of Banking \& Finance, 2953-2968.

Mace, F. C., Shapiro, E. S., West, B. J., Campbell, C., \& Altman, J. (1986). The role of reinforcement in reactive self-monitoring. Applied Research in Mental Retardation, 7(3), 315-327.

Magdi, R., \& Nadereh, C. (2002). Corporate governance practice and performance.

Makarim, \& Supit, T. (2014, March). Indonesian Stock Exchange Regulates The Office Term Of Independent Directors And Independent Commissioners. From Makarim \& Taira S: https://www.makarim.com/en/news/detail/legalupdate/138/indonesian-stock-exchange-regulates-the-office-term-ofindependent-directors-and-independent-commissioners.

Uche, C. (2004). Corporate governance in Nigerian financial industry. Chartered Institute of Bankers of Nigeria Journal, 2, 11-23.

Wolfensohn, J. D. (1999). A battle for corporate honesty. The Economist: The World in, 1999, 38.

Zhu, J., Ye, K., Tucker, J., \& Chan, K. (2016). Board hierarchy, independent directors, and firm value: evidence from China. Journal of Corporate Finance, 362-379. 